\title{
Non-neuropathic Gaucher disease presenting in infancy
}

\author{
P. HODSON, J. GOLDBLATT, AND P. BEIGHTON
}

Red Cross War Memorial Children's Hospital, Rondebosch, University of Cape Town, and Groote Schuur Hospital, Cape Town

SUMMARY The non-neuropathic form of Gaucher disease was diagnosed in 11 children of nonJewish ancestry in South Africa; all were under the age of 4. None had any neurological involvement and, apart from the precocious presentation and rapid course, the features in each resembled those of the classical 'adult' or chronic non-neuropathic form of Gaucher disease. By contrast, the condition presented after puberty in 24 out of 28 Ashkenazi Jews who were studied during the same investigation. Activity of $\beta$-glucosidase was defective in both groups of patients and they could not be distinguished by histological criteria. Only one child with the infantile neuropathic form of Gaucher disease was identified during the survey. The preponderance of the atypical non-neuropathic form of the disorder in young children is of practical importance from the point of view of differential diagnosis in any child with hepatosplenomegaly.

Gaucher disease is conventionally classified into three types: the adult or chronic non-neuropathic, the acute neuropathic infantile, and the subacute neuropathic juvenile (Fredrickson and Sloan, 1972).

The adult or chronic non-neuropathic form is characterised by splenomegaly, dyshaemopoeisis, and orthopaedic complications, in the absence of any neurological involvement. This entity has an overwhelming predilection for Ashkenazi Jews and is by far the most common form of Gaucher disease (Matoth and Fried, 1965). In the infantile type cerebrosides accumulate in the brain and death occurs before age 2 . The rare, poorly defined juvenile type has onset in later childhood, involvement of the central nervous system, and a subacute course.

In a survey of all forms of Gaucher disease in South Africa in which 46 patients were investigated we found 13 young children with non-neuropathic Gaucher disease. In 11 of these, the disorder was diagnosed by age 4 . As this condition usually presents in adulthood, this precocious onset is a matter of considerable clinical importance. A typical case is reported and details of the manifestations in the other affected children are tabulated and dis-

Department of Paediatrics, Red Cross War Memorial Children's Hospital, Rondebosch

P. HODSON, senior house officer

Department of Human Genetics, University of Cape Town

Medical School, South Africa

J. GOLDBLATT, senior house officer

P. BEIGHTON, professor of human genetics cussed in order to arouse diagnostic awareness and to emphasise that the non-neuropathic form of Gaucher disease can occur in infancy.

\section{Patients and methods}

Since 1971, attempts have been made to examine and investigate every patient with Gaucher disease in South Africa. So far 46 with the chronic nonneuropathic form have been studied and in each the diagnosis was confirmed histologically or by demonstration of defective leucocyte $\beta$-glucosidase activity. Of these patients 28 were Ashkenazi Jews, 10 were Afrikaners, 3 were of mixed ancestry, 2 were African Negroes, and 3 were British. The survey methodology and the findings in the Ashkenazim have been reported elsewhere (Beighton and Sacks, 1974; Myers et al., 1975; Goldblatt et al., 1978). The genetic implications of Gaucher disease in the Afrikaners, including 7 of the patients in the present series, have also been reported (Goldblatt and Beighton, 1979b).

Surprisingly, the so-called 'adult' non-neuropathic form of Gaucher disease was diagnosed before age 4 in 11 patients, and at 6 and 8 years in 2 others. Apart from a pair of siblings in a Sephardic-Ashkenazi family, all these children were Afrikaners or of mixed ancestry. By contrast, the condition was clinically apparent in only 4 of the 28 Ashkenazi Jews before puberty and their symptoms were slight. 
The classical infantile neuropathic form of Gaucher disease was found in only one patient, a baby born to a consanguineous Indian couple.

Personal and clinical data on the children with non-neuropathic Gaucher disease are shown in the Table, and a brief case report is given below.

Case report. Case 9, the only child of nonconsanguineous parents of mixed ancestry was born in 1974. He weighed $2.6 \mathrm{~kg}$ at birth and his neonatal course was complicated by jaundice, for which he received phototherapy.

He had several episodes of croup and bronchospasm during infancy and, at age 2, hepatosplenomegaly was detected during routine examination. Histological studies of bone marrow were undertaken and the diagnosis of Gaucher disease was established. Up to this point, his developmental milestones had been normal.

He was then lost to follow-up until, at age $3 \frac{1}{2}$, he again presented with shortness of breath and pyrexia. At this stage his abdomen was distended by a huge spleen which extended into the right iliac fossa, and the liver projected $10 \mathrm{~cm}$ below the inferior costal border (Figure). No abnormality could be detected in his central nervous system.

At this time he was pancytopenic with $\mathrm{Hb} 6 \cdot 3$

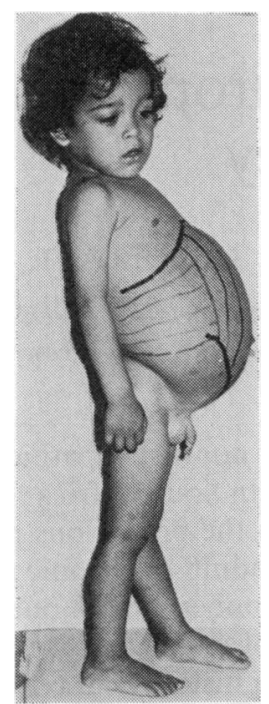

Figure 3-year-old child (Case 9) with Gaucher disease. Massive hepatosplenomegaly is evident.

$\mathrm{g} / \mathrm{dl}$, a platelet count of $35.0 \times 10^{9} / 1$ and total WBC of $3.4 \times 10^{\%} / 1$, of which $8 \%$ were polymorphs.

During his stay in hospital he had several episodes of massive epistaxis which were attributed to his

Table Clinical manifestations of children with non-neuropathic Gaucher disease

\begin{tabular}{|c|c|c|c|c|c|c|c|c|c|}
\hline \multirow[t]{2}{*}{ Case } & \multirow[t]{2}{*}{ Sex } & \multirow[t]{2}{*}{ Ethnic group } & \multirow{2}{*}{$\begin{array}{l}\text { Age at } \\
\text { diagnosis } \\
\text { (years) }\end{array}$} & \multirow{2}{*}{ Presenting feature } & \multicolumn{3}{|l|}{ Complications } & \multirow[t]{2}{*}{ Management } & \multirow{2}{*}{$\begin{array}{l}\text { Family } \\
\text { history }\end{array}$} \\
\hline & & & & & Skeletal & Haematolcgical & Other & & \\
\hline 1 & $\mathbf{F}$ & Afrikaner & $1 \frac{1}{2}$ & Splenomegaly & 一 & Hypersplenism & 一 & Splenectomy & - \\
\hline 2 & $\mathbf{F}$ & Afrikaner & $3 \frac{1}{2}$ & Splenomegaly & $\begin{array}{l}\text { Pseudo-osteo- } \\
\text { myelitis }\end{array}$ & $\begin{array}{l}\text { Thrombocyto- } \\
\text { penia }\end{array}$ & - & Splenectomy & $\begin{array}{l}\text { Brother } \\
\text { (Case 3) }\end{array}$ \\
\hline 3 & $\mathbf{M}$ & Afrikaner & $3 \frac{1}{2}$ & $\begin{array}{l}\text { Splenomegaly. } \\
\text { Epistaxis }\end{array}$ & Bone pain & $\begin{array}{l}\text { Thrombocyto- } \\
\text { penia }\end{array}$ & - & Splenectomy & $\begin{array}{l}\text { Sister } \\
\quad \text { (Case 2) }\end{array}$ \\
\hline 4 & $\mathbf{F}$ & Afrikaner & 2 & Splenomegaly & $\begin{array}{l}\text { Pseudo-osteo- } \\
\text { myelitis. } \\
\text { Pathological } \\
\text { fractures }\end{array}$ & Hypersplenism & $\begin{array}{l}\text { Pulmonary } \\
\text { infiltration. } \\
\text { Sexual infan- } \\
\text { tilism. Died } \\
\text { age } 16\end{array}$ & - & - \\
\hline 5 & $\mathbf{M}$ & Afrikaner & 6 & $\begin{array}{l}\text { Hepatospleno- } \\
\text { megaly }\end{array}$ & 一 & Hypersplenism & $\begin{array}{l}\text { Recurrent } \\
\text { respiratory } \\
\text { infections }\end{array}$ & 一 & $\begin{array}{c}\text { Affected } \\
\text { sister? }\end{array}$ \\
\hline 6 & $\mathbf{F}$ & Afrikaner & 1 & $\begin{array}{l}\text { Hepatospleno- } \\
\text { megaly }\end{array}$ & 一 & - & 一 & 一 & $\begin{array}{l}2 \text { adult } \\
\text { relatives } \\
\text { affected }\end{array}$ \\
\hline 7 & $\mathbf{F}$ & $\begin{array}{l}\text { Mixed } \\
\text { ancestry }\end{array}$ & 8 & $\begin{array}{l}\text { Hepatospleno- } \\
\text { megaly }\end{array}$ & 一 & $\begin{array}{l}\text { Thrombocyto- } \\
\text { penia }\end{array}$ & 一 & 一 & $\begin{array}{l}\text { Brother } \\
\text { (Case 8) }\end{array}$ \\
\hline 8 & $\mathbf{M}$ & $\begin{array}{l}\text { Mixed } \\
\text { ancestry }\end{array}$ & $3 \frac{1}{2}$ & $\begin{array}{l}\text { Respiratory } \\
\text { infections. } \\
\text { Anaemia }\end{array}$ & 一 & $\begin{array}{l}\text { Thrombocyto- } \\
\text { penia }\end{array}$ & $\begin{array}{l}\text { Recurrent } \\
\text { respiratory } \\
\text { infections }\end{array}$ & 一 & $\begin{array}{l}\text { Sister } \\
\quad \text { (Case 7) } \\
\text { 3rd sibling } \\
\text { probably } \\
\text { affected }\end{array}$ \\
\hline 9 & $\mathbf{M}$ & $\begin{array}{l}\text { Mixed } \\
\text { ancestry }\end{array}$ & 2 & $\begin{array}{l}\text { Hepatospleno- } \\
\text { megaly }\end{array}$ & $\begin{array}{l}\text { Rib and } \\
\text { clavicle } \\
\text { involvement }\end{array}$ & Hypersplenism & $\begin{array}{l}\text { Recurrent } \\
\text { respiratory } \\
\text { infections }\end{array}$ & 一 & 一 \\
\hline 10 & $\mathbf{M}$ & $\begin{array}{l}\text { Afrikaner- } \\
\text { Hungarian }\end{array}$ & $1 \frac{1}{2}$ & Hepatomegaly & $\begin{array}{l}\text { Arthritis. } \\
\text { Fractured } \\
\text { femoral reck }\end{array}$ & 一 & - & Splenectomy & 一 \\
\hline 11 & $\mathbf{F}$ & $\begin{array}{l}\text { Ashkenazi- } \\
\text { Sephardic }\end{array}$ & 4 & $\begin{array}{l}\text { Malaise. } \\
\text { Splenomegaly }\end{array}$ & 一 & Hypersplenism & 一 & 一 & $\begin{array}{l}\text { Sister } \\
\text { (Case 12) }\end{array}$ \\
\hline 12 & $\mathbf{F}$ & $\begin{array}{l}\text { Ashkenazi- } \\
\text { Sephardic }\end{array}$ & 3 & $\begin{array}{l}\text { Croup. } \\
\text { Splenomegaly }\end{array}$ & - & Hypersplenism & - & - & $\begin{array}{l}\text { Sister } \\
\text { (Case 11) }\end{array}$ \\
\hline
\end{tabular}


thrombocytopenia. Cardiac failure developed after numerous blood transfusions, and treatment with digitalis was eventually needed.

$\beta$-Glucosidase activity in cultured fibroblasts obtained after skin biopsy was markedly diminished. His mother had intermediate levels of activity in her own cultured fibroblasts, and this was taken to be indicative of her status as a heterozygote for the Gaucher disease gene. The father was not available for investigation.

The patient is now aged $3 \frac{3}{4}$ years. He experiences considerable malaise and his activity is impaired by the gross distension of his abdomen. He has severe hypersplenism and chronic anaemia with a large heart and borderline cardiac failure. His prognosis is considered to be poor.

\section{Discussion}

Although they share a common autosomal recessively inherited defect of the enzyme $\beta$-glucosidase (Brady, 1978), it is generally accepted that the infantile, juvenile, and adult or non-neuropathic forms of Gaucher disease are separate conditions. At a clinical level death from central nervous system involvement in the infantile and juvenile types, and the prolonged course and absence of neurological complications in the adult form, represent obvious distinctions between these entities.

The ethnic predilection of the adult form of Gaucher disease for the Ashkenazim is well known and in the Jewish community of South Africa this condition is present in about one in $\mathbf{4 0 0 0}$ (Goldblatt and Beighton, 1979a). None of our Ashkenazi Jewish patients with this type of the disorder had any neurological involvement and only 4 experienced symptoms before puberty, and these were slight. By contrast, with the exception of the pair of siblings with an Ashkenazi father and a Sephardic mother, none of the 11 children who developed symptoms before age 4 was Jewish. In these children there were no changes in the central nervous system and, apart from the precocious onset and rapid progression, the disease followed the same general course as in the Jewish patients.

The reason for this temporal discrepancy in the development of the disorder is unknown although at a fundamental genetic level allelism or epistasis could be invoked as possible explanations. In view of the nature of our survey methodology, it is unlikely that ascertainment bias or inadequate case investigation could be responsible for this paradox. It is interesting that there was no correlation between the magnitude of the enzymatic defect and the severity of clinical manifestations in any patient.

The occurrence of non-neuropathic Gaucher disease in infancy was noted 40 years ago (Aballi and
Kato, 1938), but this form of the condition has been ignored in conventional classifications. However, in a report of these infants with hepatosplenomegaly, Schneider et al. (1977) drew attention to early onset and rapid progression in certain non-neuropathic cases.

The magnitude of the problem of early presentation is highlighted by the fact that we found only one patient with the classical infantile neuropathic type of Gaucher disease, in contrast with the 13 children who had the atypical non-neuropathic form. This 13-fold preponderance is of considerable importance from the point of view of differential diagnosis in any child with unexplained hepatosplenomegaly.

We thank our colleagues at the Red Cross War Memorial Hospital and other centres for access to their patients, R. A. De Méneaud for the illustration, and Mrs Greta Beighton and Mrs Barbara Breytenbach for typing the manuscript.

This investigation was supported by grants from the Mauerberger Foundation, the University of Cape Town Staff Research Fund, and the South African Medical Research Council.

\section{References}

Aballi, A. J., and Kato K. (1938). Gaucher's disease in early infancy. Journal of Pediatrics, 13, 364-380.

Beighton, P., and Sacks, S. (1974). Gaucher's disease in southern Africa. South African Medical Journal, 48, 1295-1299.

Brady, R. O. (1978). Sphingolipidoses. Annual Review of Biochemistry, 47, 687-713.

Fredrickson, D. S., and Sloan, H. R. (1972). Glucosyl ceramide lipidoses: Gaucher's disease. In Metabolic Basis of Inherited Disease, third edition, pp. 730-759. Edited by J. B. Stanbury, J. B. Wyngaarden, and D. S. Fredrickson. McGraw-Hill: New York.

Goldblatt, J., Sacks, S., and Beighton, P. (1978). Orthopaedio aspects of Gaucher's disease. Clinical Orthopaedics, 137, 208-214.

Goldblatt, J., and Beighton, P. (1979a). Gaucher's disease in South Africa. Journal of Medical Genetics, 16, 302-305.

Goldblatt, J., and Beighton, P. (1979b).Gaucher disease in the Afrikaner population of South Africa. South African Medical Journal, 55, 209-210.

Matoth, Y., and Fried, K. (1965). Chronic Gaucher's disease. Clinical observations on 34 patients. Israel Journal of Medical Sciences, 1, 521-530.

Myers, H. S., Cremin, B. J., Beighton, P., and Sacks, S. (1975). Chronic Gaucher's disease: radiological findings in 17 South African cases. British Journal of Radiology, 48, 465-469.

Schneider, E. L., Epstein, C. J., Kaback, M. J., and Brandes, D. (1977). Severe pulmonary involvement in adult Gaucher's. disease. American Journal of Medicine, 63, 475-480.

Correspondence to Professor P. Beighton, Department of Human Genetics, University of Cape Town Medical School, Observatory 7925, South Africa.

Received 31 October 1978 